\title{
AN ANALYTICAL STUDY IN INVESTMENT, MARKETING AND MEDIA ACCORDING TO THE STRATEGIC ANALYSIS METHOD (SWOT) OF THE INTERNAL ENVIRONMENT OF IRAQI SPORTS CLUBS
}

Fadel Risan Faraj Al-Hamdani, Prof.Dr. Asaad Lazim Ali

University of Baghdad / College of Physical Education and Sports Sciences

DOI: $10.37648 /$ ijrssh.v10i02.024

Received: $30^{\text {th }}$ March, 2020; Accepted: $20^{\text {th }}$ April, 2020; Published: $13^{\text {th }}$ May,2020

\section{ABSTRACT}

The importance of the research was demonstrated through the development of an analytical study of the reality of investment, marketing and media according to the strategic analysis method (SWOT) of the internal environment of Iraqi sports clubs, as there are several factors that led to many obstacles to sports investment and marketing and the identification of strengths and weaknesses and the most important challenges facing the internal environment. The researcher has used The survey method on the sample of the application sample from (154) forms representing the responses of the sample. The research sample was chosen randomly. A questionnaire was designed containing (2) axis containing several paragraphs that included many aspects of the internal environment according to the system (SWOC) and After distributing the questionnaire and collecting the results, the researcher reached the following conclusions. The sport clubs departments in Iraq have a weak level of the internal environment in investment, marketing and sports media.

INTRODUCTION

Sports clubs sought to employ all resources, material and moral capabilities, in order to overcome all difficulties and obstacles facing clubs departments and their sports teams and the current and future changes affecting them, as well as finding the best ways to respond to rapid changes in the internal and external environment such as the Asian license and the field of investment and marketing of athletes and Privatization, therefore, the administrative authorities have the greatest responsibility in upgrading the sports institutions, whether it is a sports club or a sports federation in order to create an ideal investment and marketing environment, as well as developing material means. In order to have a permanent activity in which characteristically without hindrance to remember. The media is an integral part of the general policy of any country and it is an application of its policy through which it seeks to direct the public towards a specific policy for the state, as the most important tasks of sports media are to spread the diverse sports culture as well as to promote all kinds of sports, and to communicate all information and news to athletes and workers in the field The athlete in general and the receiver put the viewer with all the details 
(IJRSSH) 2020, Vol. No. 10, Issue No. II, Apr-Jun

about the events and tournaments and the results that are achieved in various international tournaments. The importance of research is highlighted by creating a solid economy that depends on sports investment and marketing, which has become one of the most important priorities for sports departments in the modern era, and this is only possible through finding the necessary and realistic mechanisms at work, and here the role of the strategic analysis system (SWOT) for the internal environment is highlighted to become a necessity It is urgent to show the facts and provide the optimal solution for many sports institutions. Therefore, the sports institution must understand its internal environment and analyze the strengths and weaknesses therein, in order to determine the best ways to respond to rapid changes and invest them towards achieving the best performance for them. The mathematics of internal environmental analysis by reinforcing strengths, and overcoming weaknesses

:Research problem

Through the work of the researcher in the field of sports media and his direct knowledge of the reality of the state of sports clubs, it is noticed that there is a clear variation in the nature of the work of the Iraqi sports club departments and their inability to achieve success and how to get away from the crises or threats that confuse its work, and perhaps the most important reasons facing it are the physical challenges Which causes great suffering for athletes, coaches and workers within these clubs, as a result of the high rates of payments over income ratios and the impact of this on the course of work of the club, which seeks to provide future services that put it on the right track. Therefore, it is required from the departments of these clubs to study the strategic analysis to determine their current and future goals and find a suitable investment and marketing environment through which these threats and financial crises are overcome, all this prompted the researcher to study this problem an extensive analytical and scientific study according to the (swot) model for the internal environment (point analysis) Strength and Weakness) in the fields of sports investment and marketing, and preparing them in a way that suits the requirements for the advancement and development of club management work, and helps them in achieving the positive relationship between strategic environmental analysis and the goals they seek to achieve research aims:
e-ISSN: 2249-4642, p-ISSN: 2454-4671

- Building a scale for investment, marketing and media for Iraqi sports clubs according to the "swot" model. For the interior environment.

- Knowing the reality of investment, marketing and sports media in accordance with the (swot) model for the internal environment of Iraqi sports clubs.

:Research areas

:The Human Domain

Members of the administrative bodies working in Iraqi sports clubs

:For the temporal domain

Duration from 01/28/2019 to 2/12/2019

:Spatial domain

.Sports club headquarters -

:Defining terms

Swot Model Analysis of the Internal Environment: "The administration undertakes strategic analysis of the surrounding environmental forces because of the importance of its impact on its goals and activities, knowing the competitive advantages in order to control its internal environment, in a way that helps the administration achieve the positive relationship between strategic environmental analysis and its required strategic goals".

\section{MATERIALS AND METHODS:}

\section{Research Methodology:}

The researcher used the descriptive method in the survey method that "descriptive research. Aims to study the current conditions of phenomena in terms of their characteristics or forms, their relationships, and the factors affecting them" .

\section{Search community and sample:}

The research community was chosen intentionally. And represented by the heads and members of the administrative bodies of sports clubs in Iraq affiliated with the Ministry of Youth and Sports / Department of Sports Clubs and to determine the size of the total research community, which amounted to (300) clubs and number (2100) member of the administrative body, according to the book of the Ministry of Youth and Sports / Department of Physical Education and Sports / Department Sports Clubs No. 406 on 1/28/2019.

The sample means "the part that represents the community of origin or the model on which the researcher conducts his entire work" (3: 67). And "to implement the 
(IJRSSH) 2020, Vol. No. 10, Issue No. II, Apr-Jun

research steps in an accurate scientific manner, a representative sample of the parent community must be chosen" (4: 144), as the research sample was randomly selected (41) clubs from (369) members with a percentage $(17.5 \%)$ of the research community and consisted of the sample Reconnaissance of three clubs with a number (22) administratively and the construction sample consisted of (16) clubs and consisted of (122) members. After retrieving and sorting the data, (4) invalid or nonhyphenated forms were dropped as the building sample became (118) and the applied research sample by the way Randomness, as (22) clubs were chosen, and the number of the sample members reached (160), head and members of the administrative bodies of sports clubs for institutions in Iraq, and after retrieving For data and sorting, (6) invalid or non-receipted forms were dropped, as the application sample became one of (154) forms representing the responses of the sample.

\section{Means of gathering information, tools and devices used} in research:

Arab and foreign sources. -

). International Electronic Information Network (Internet Phrase Survey Questionnaire (for S.O.W.T scale). -

-Personal interviews.

\section{Field research procedures:}

\section{: Standard Building Procedures}

For the purpose of building the scale of investment, marketing and sports media according to the model ((S.O.W.T for Iraqi sports clubs), the researcher followed the steps outlined by each of (Kronbach 1970) (14: 469) as it indicates that the process of building any scale goes through the following steps:

\section{:The purpose of building a scale}

The first step to building a specific scale is to clearly define the purpose of the scale and what is the intended use of this scale, which is to identify the reality of investment, marketing and sports media for Iraqi sports clubs, so the current research required building a scale of investment, marketing and sports media according to the

\section{e-ISSN: 2249-4642, p-ISSN: 2454-4671}

model ((SOWT of Iraqi sports clubs) To achieve the research goal.

:Defining Scale Areas

Where the first letter $(\mathrm{S})$ indicates the strength field of the organization (Strengths and the second letter) (W) indicates the field of Weaknesses

Define the method for drafting paragraphs of scale .

The researcher relied on the formulation of the scale paragraphs on the Likert method, which is similar to the multiple choice method, which is one of the common methods of measurement in educational and psychological research, as it presents the respondent with a position and asks him to determine his answer by choosing an alternative from several alternatives that have different weights he is:

\section{:Validity of Paragraphs (Logical Analysis)}

After having prepared the paragraphs of the scale of (36), which the researcher intends to present these paragraphs in their preliminary form, as attached by Appendix (3) to a group of (9) of experts and specialists in the field of sports management, economics, tests, measurement and Appendix (1). For the purpose of judging them in terms of drafting paragraphs or their validity in measuring the concept of investment, marketing and sports media for Iraqi sports clubs, they were asked to diagnose valid paragraphs of their lack thereof as well as the proposed amendment or formulate new paragraphs needed by the field, and after collecting the opinions of experts, the researcher took the paragraph agreed upon The news By (75\%) and above, it has been deleted paragraph (19) of the axis of power and paragraph (16) of the axis of weakness

\section{.Correcting the scale}

To correct the scale, the researcher followed the Lekart method, and after collecting the forms, the administrators 'answers (the construction sample) were corrected using a five-point correction key, which is" the tool by which the result of the answers that indicate the variables measured "is corrected (5: 114), for its negative and positive paragraphs in Grades are calculated according to Table (1). 
Table (1): Shows the alternatives and their weights

\begin{tabular}{|l|l|l|l|l|l|}
\hline very much & Much & Sometimes & Scarcely & $\begin{array}{l}\text { very } \\
\text { seldom }\end{array}$ & Alternatives \\
\hline $\mathbf{5}$ & $\mathbf{4}$ & $\mathbf{3}$ & $\mathbf{2}$ & $\mathbf{1}$ & Positive direction \\
\hline $\mathbf{1}$ & $\mathbf{2}$ & $\mathbf{3}$ & $\mathbf{4}$ & $\mathbf{5}$ & Negative direction \\
\hline
\end{tabular}

Scale levels:

Levels of the scale were found, based on the range method, according to the estimation of the grades of the fifth scale (Likert method). The level was divided as follows:

Table (2)

Shows percentage and levels

\begin{tabular}{|l|l|l|l|c|}
\hline Level type & percentage & the middle & Level type & sequence \\
\hline Low & 0.2 to 0.36 & From 1 to less 1,8 & level one & $\mathbf{1}$ \\
\hline Acceptable & 0.36 to 0.52 & 1,81 to less 2,6 & Second Level & $\mathbf{2}$ \\
\hline The average & 0.52 to 0.68 & 2.61 to less 3.4 & The third level & $\mathbf{3}$ \\
\hline good & 0.68 to 0.84 & 3.41 to less 4.2 & fourth level & $\mathbf{4}$ \\
\hline High & 0.84 to 100 & 4.21 to the lowest 5 & level five & $\mathbf{5}$ \\
\hline
\end{tabular}

Construction experience:

The experiment of building was conducted on a sample of (122) administrators distributed on sports clubs, as the special forms were distributed by the assistant work team on (5/26/2019), and the Ministry of Youth and Sports / Department of Physical and Sports Education / Department of Sports Clubs was also hired Addressing sports clubs in the Iraqi governorates with the love of book number (2276) on 6/13/2019 in sending the questionnaire to all clubs as the sample was randomly chosen and the purpose of the experiment was to conduct scientific transactions for the scale and after retrieving and sorting the data, (4) forms were dropped Not valid or not hyphen as it became The construction sample of (118) forms represents the responses of the construction sample

Psychometric properties of the scale:

A: Certify content:

- Al-Dhahri Sadiq: which indicates the relevance of the scale paragraphs to the variable to be measured. This indicator of truth is achieved "when a person related to the subject decides that the scale is appropriate for the characteristic to be measured, and this may be an expert" The apparent truth of the scale was achieved when the scale was presented in its primary form to a group of experts to judge the validity of its paragraphs in measuring.

- Logical honesty: This indicator of honesty was available in the current scale when starting the preparation of the scale through the definition of the concept of the scale of investment, marketing and sports media according to a model (S.O.W.T) for the internal environment of Iraqi sports clubs and defining its areas and paragraphs.

B: Construct Validity.

First: the discriminatory power of the paragraphs.

The answers of all of the 118 sample respondents were excluded. The total score was determined for each of the forms. The forms were arranged in descending order from the highest to the lowest. Then the upper (27\%) percentage was chosen with the number of (32) forms, and the lowest (27\%) with the number of (32) forms from the grades to represent the extremist group 
(IJRSSH) 2020, Vol. No. 10, Issue No. II, Apr-Jun

e-ISSN: 2249-4642, p-ISSN: 2454-4671

and excluding the (46\%) mean with the number of (54) forms and then the test (t. test) for the purpose of calculating the discrimination factor for each of the paragraphs of the scale of (34) and the results have shown that the calculated significance level is smaller than the value of the approved significance level (0.05), which means the significance of the values of (calculated) all calculated and for all paragraphs except for paragraphs (12)

Table (3)

\begin{tabular}{|c|c|c|c|c|c|c|}
\hline \multirow[t]{2}{*}{ indication } & \multirow[t]{2}{*}{ Error level } & \multirow[t]{2}{*}{ Value of $\mathrm{t}$} & \multicolumn{2}{|c|}{ Statistical parameters } & \multirow[t]{2}{*}{ the group } & \multirow[t]{2}{*}{ Paragraph } \\
\hline & & & $\begin{array}{l}\text { standard } \\
\text { deviation }\end{array}$ & $\begin{array}{l}\text { Arithmetic } \\
\text { mean }\end{array}$ & & \\
\hline \multirow[t]{2}{*}{ moral } & \multirow[t]{2}{*}{0.003} & \multirow[t]{2}{*}{3.123} & 1.03954 & 3.8750 & Upper group & \multirow{2}{*}{1} \\
\hline & & & 1.34254 & 2.9375 & Lower group & \\
\hline \multirow[t]{2}{*}{ moral } & \multirow[t]{2}{*}{0.000} & \multirow[t]{2}{*}{5.265} & 1.11034 & 3.8438 & Upper group & \multirow{2}{*}{2} \\
\hline & & & 1.07341 & 2.4063 & Lower group & \\
\hline \multirow[t]{2}{*}{ moral } & \multirow[t]{2}{*}{0.026} & \multirow[t]{2}{*}{2.28} & 1.37335 & 3.2813 & Upper group & \multirow{2}{*}{3} \\
\hline & & & 1.01153 & 2.5938 & Lower group & \\
\hline \multirow[t]{2}{*}{ moral } & \multirow[t]{2}{*}{0.000} & \multirow[t]{2}{*}{6.256} & 0.96668 & 4.0313 & Upper group & \multirow{2}{*}{4} \\
\hline & & & 1.18074 & 2.3438 & Lower group & \\
\hline \multirow[t]{2}{*}{ moral } & \multirow[t]{2}{*}{0.001} & \multirow[t]{2}{*}{3.609} & 1.07341 & 3.5938 & Upper group & \multirow{2}{*}{5} \\
\hline & & & 1.00352 & 2.6563 & Lower group & \\
\hline \multirow[t]{2}{*}{ moral } & \multirow[t]{2}{*}{0.162} & \multirow[t]{2}{*}{1.415} & 1.2504 & 3.2813 & Upper group & \multirow{2}{*}{6} \\
\hline & & & 1.56028 & 2.7813 & Lower group & \\
\hline \multirow[t]{2}{*}{ moral } & \multirow[t]{2}{*}{0.000} & \multirow[t]{2}{*}{5.57} & 1.17732 & 3.9688 & Upper group & \multirow{2}{*}{7} \\
\hline & & & 0.91581 & 2.5000 & Lower group & \\
\hline moral & 0.000 & 6.501 & 0.88843 & 4.2813 & Upper group & \\
\hline & & & 1.27 & 2.5000 & Lower group & $\gamma$ \\
\hline moral & 0.000 & 4.352 & 1.20106 & 3.9063 & Upper group & \\
\hline & & & 1.26841 & 2.5625 & Lower group & 9 \\
\hline moral & 0.000 & 4.624 & 1.37811 & 3.8125 & Upper group & \\
\hline & & & 1.1531 & 2.3438 & Lower group & 10 \\
\hline moral & 0.02 & 2.39 & 1.10671 & 3.5313 & Upper group & 11 \\
\hline
\end{tabular}




\begin{tabular}{|c|c|c|c|c|c|c|}
\hline & & & 1.48106 & 2.7500 & Lower group & \\
\hline \multirow[t]{2}{*}{ random } & \multirow[t]{2}{*}{0.113} & \multirow[t]{2}{*}{1.608} & 1.11984 & 3.6875 & Upper group & \multirow{2}{*}{12} \\
\hline & & & 1.21109 & 3.2188 & Lower group & \\
\hline \multirow[t]{2}{*}{ moral } & \multirow[t]{2}{*}{0.002} & \multirow[t]{2}{*}{3.157} & 1.09939 & 3.7813 & Upper group & \multirow{2}{*}{13} \\
\hline & & & 1.11758 & 2.9063 & Lower group & \\
\hline \multirow[t]{2}{*}{ moral } & \multirow[t]{2}{*}{0.000} & \multirow[t]{2}{*}{3.697} & 1.09203 & 4.0313 & Upper group & \multirow{2}{*}{14} \\
\hline & & & 1.26841 & 2.9375 & Lower group & \\
\hline \multirow[t]{2}{*}{ moral } & \multirow[t]{2}{*}{0.000} & \multirow[t]{2}{*}{4.988} & 0.89747 & 3.9688 & Upper group & \multirow{2}{*}{15} \\
\hline & & & 1.3183 & 2.5625 & Lower group & \\
\hline \multirow[t]{2}{*}{ moral } & \multirow[t]{2}{*}{0.031} & \multirow[t]{2}{*}{2.208} & 1.38504 & 3.7813 & Upper group & \multirow{2}{*}{16} \\
\hline & & & 1.33161 & 3.0313 & Lower group & \\
\hline \multirow[t]{2}{*}{ moral } & \multirow[t]{2}{*}{0.000} & \multirow[t]{2}{*}{4.79} & 1.06208 & 4.0313 & Upper group & \multirow{2}{*}{17} \\
\hline & & & 1.07763 & 2.7500 & Lower group & \\
\hline \multirow[t]{2}{*}{ moral } & \multirow[t]{2}{*}{0.000} & \multirow[t]{2}{*}{3.834} & 1.13592 & 4.0000 & Upper group & \multirow{2}{*}{18} \\
\hline & & & 1.27278 & 2.8438 & Lower group & \\
\hline \multirow[t]{2}{*}{ moral } & \multirow[t]{2}{*}{0.000} & \multirow[t]{2}{*}{2.846} & 1.04727 & 3.5000 & Upper group & \multirow{2}{*}{19} \\
\hline & & & 1.22967 & 2.6875 & Lower group & \\
\hline \multirow[t]{2}{*}{ moral } & 0.000 & 3.557 & 1.40132 & 3.6875 & Upper group & \\
\hline & & & 1.19094 & 2.5313 & Lower group & 20 \\
\hline moral & 0.000 & 4.382 & 1.09985 & 3.8750 & Upper group & \\
\hline & & & 1.12478 & 2.6563 & Lower group & 21 \\
\hline moral & 0.000 & 3.288 & 1.18074 & 3.6563 & Upper group & \\
\hline & & & 1.17604 & 2.6875 & Lower group & 22 \\
\hline moral & 0.000 & 5.324 & 1.12478 & 3.6563 & Upper group & \\
\hline & & & 0.98374 & 2.2500 & Lower group & 23 \\
\hline moral & 0.000 & 3.98 & 1.29515 & 3.7500 & Upper group & 24 \\
\hline
\end{tabular}




\begin{tabular}{|c|c|c|c|c|c|c|}
\hline & & & 1.01153 & 2.5938 & Lower group & \\
\hline \multirow[t]{2}{*}{ moral } & \multirow[t]{2}{*}{0.000} & \multirow[t]{2}{*}{5.185} & 0.96512 & 4.1875 & Upper group & \multirow{2}{*}{25} \\
\hline & & & 1.14828 & 2.8125 & Lower group & \\
\hline \multirow[t]{2}{*}{ moral } & \multirow[t]{2}{*}{0.000} & \multirow[t]{2}{*}{4.032} & 1.016 & 3.7500 & Upper group & \multirow{2}{*}{26} \\
\hline & & & 1.09065 & 2.6875 & Lower group & \\
\hline \multirow[t]{2}{*}{ moral } & \multirow[t]{2}{*}{0.001} & \multirow[t]{2}{*}{3.619} & 1.18755 & 3.4063 & Upper group & \multirow{2}{*}{27} \\
\hline & & & 1.22967 & 2.3125 & Lower group & \\
\hline \multirow[t]{2}{*}{ moral } & \multirow[t]{2}{*}{0.000} & \multirow[t]{2}{*}{5.532} & 0.97551 & 3.8750 & Upper group & \multirow{2}{*}{28} \\
\hline & & & 0.87471 & 2.5938 & Lower group & \\
\hline \multirow[t]{2}{*}{ moral } & \multirow[t]{2}{*}{0.044} & \multirow[t]{2}{*}{2.058} & 1.16398 & 3.2500 & Upper group & \multirow{2}{*}{29} \\
\hline & & & 1.26364 & 2.6250 & Lower group & \\
\hline \multirow[t]{2}{*}{ moral } & \multirow[t]{2}{*}{0.002} & \multirow[t]{2}{*}{3.241} & 1.20775 & 3.6563 & Upper group & \multirow{2}{*}{30} \\
\hline & & & 1.26004 & 2.6563 & Lower group & \\
\hline \multirow[t]{2}{*}{ moral } & \multirow[t]{2}{*}{0.000} & \multirow[t]{2}{*}{4.25} & 1.26642 & 3.5938 & Upper group & \multirow{2}{*}{31} \\
\hline & & & 0.9456 & 2.4063 & Lower group & \\
\hline \multirow[t]{2}{*}{ moral } & \multirow[t]{2}{*}{0.000} & \multirow[t]{2}{*}{3.718} & 1.19094 & 3.5313 & Upper group & \multirow{2}{*}{32} \\
\hline & & & 1.16224 & 2.4375 & Lower group & \\
\hline \multirow[t]{2}{*}{ moral } & \multirow[t]{2}{*}{0.005} & \multirow[t]{2}{*}{2.891} & 1.38541 & 3.3750 & Upper group & \\
\hline & & & 1.10671 & 2.4688 & Lower group & 33 \\
\hline moral & 0.002 & 3.215 & 1.016 & 3.7500 & Upper group & \\
\hline & & & 1.43684 & 2.7500 & Lower group & 34 \\
\hline
\end{tabular}

At a degree of freedom (62) and the significance level $(0,05)$ Second: the coherence coefficient of internal (relationship of the degree of the paragraph to the total degree):

" The coherence coefficient is used, to provide us with evidence for the homogeneity of the paragraphs," "The coherence coefficient is the coefficient of correlation between the scores of each paragraph and the overall degree of scale." To find the coefficient of coherence, Pearson correlation coefficient is used between the degree of Each paragraph and the total score for the scale and for all individuals of the sample of (118) and all of the paragraphs were approved, and thus (33) paragraphs remain for measuring investment, marketing and sports media according to the model (SOWT) for the internal environment of Iraqi sports clubs) and table (4) shows that. 
Table (4)

Pearson Simple Correlation Coefficients for Scale Paragraph Validity

\begin{tabular}{|c|c|c|c|c|c|}
\hline Error level & $\begin{array}{l}\text { Their } \\
\text { coefficient of } \\
\text { correlation }\end{array}$ & $\begin{array}{l}\text { Paragraph } \\
\text { number }\end{array}$ & Error level & $\begin{array}{l}\text { Their } \\
\text { coefficient of } \\
\text { correlation }\end{array}$ & $\begin{array}{l}\text { Paragraph } \\
\text { number }\end{array}$ \\
\hline 0.000 & 0.575 & 18 & 0.000 & 0.385 & 1 \\
\hline 0.000 & 0.430 & 19 & 0.000 & 0.483 & 2 \\
\hline 0.000 & 0.453 & 20 & 0.015 & 0.224 & 3 \\
\hline 0.000 & 0.549 & 21 & 0.000 & 0.372 & 4 \\
\hline 0.000 & 0.465 & 22 & 0.000 & 0.412 & 5 \\
\hline 0.000 & 0.519 & 23 & 0.000 & 0.401 & 6 \\
\hline 0.000 & 0.468 & 24 & 0.000 & 0.667 & 7 \\
\hline 0.000 & 0.390 & 25 & 0.000 & 0.535 & 8 \\
\hline 0.000 & 0.570 & 26 & 0.000 & 0.497 & 9 \\
\hline 0.000 & 0.575 & 27 & 0.000 & 0.590 & 10 \\
\hline 0.000 & 0.528 & 28 & 0.000 & 0.554 & 11 \\
\hline 0.000 & 0.402 & 29 & 0.000 & 0.503 & 12 \\
\hline 0.000 & 0.484 & 30 & 0.000 & 0.476 & 13 \\
\hline 0.000 & 0.327 & 31 & 0.000 & 0.481 & 14 \\
\hline 0.000 & 0.527 & 32 & 0.000 & 0.552 & 15 \\
\hline \multirow[t]{2}{*}{0.000} & 0.425 & 33 & 0.000 & 0.421 & 16 \\
\hline & & & 0.000 & 0.576 & 17 \\
\hline
\end{tabular}

: Exploration Experience Stability of scale

First: the half-way method.

The researcher used the midterm segmentation method because it is one of the most widely used method of consistency. "This method is based on dividing the test paragraphs into two halves, the first contains the paragraphs with odd numbers and the other contains the paragraphs with even numbers, and thus this method covers equal degrees for the two halves of the paragraphs." (8: 24 Therefore, the use of questionnaires of the experimental sample amounting to (118) used a questionnaire, and the value of the correlation coefficient between the two halves reached (0.829) at an error level of $(0,000)$, and as we learned that this value shows the stability of the half of the test, so (Spearman-Brown equation) was used. Adjust the value of the half-test stability coefficient The Spearman-Brawn stability indication equation has reached the value of the stability factor of the scale $(0,906)$ and this is a good indicator as the reliable stability factor ranges between $(0.62-0.93)$ which is a high stability factor, reliable To estimate test stability.

Second: The method (Alpha Kronbach Factories).

To calculate stability with the Alpha Cronbach coefficient for the scale, its value was (0.906), which is a high reliable reliability coefficient to estimate the stability of the test.

:The objectivity of the scale

After the data was emptied from the test and repeated, it became clear that all the paragraphs were clear to the sample as they are distinguished by the fact that the alternatives are multiple choice and do not accept the answer to more than one alternative and there is no paragraph in the open answer as the questionnaire is 
(IJRSSH) 2020, Vol. No. 10, Issue No. II, Apr-Jun

highly objective and it is not possible to disagree on the degrees obtained Sample individuals.

:The basic experiment of the scale

The researcher applied the scale with the auxiliary work team, and the number of the sample members reached (160), head and members of the administrative bodies of sports clubs for institutions in Iraq. After retrieving and sorting the data, (6) invalid or non-arriving forms were dropped as the construction sample became from (154) forms representing responses The sample is on 25/25/2019 until 12/20/2019, as the number of questionnaires
e-ISSN: 2249-4642, p-ISSN: 2454-4671

distributed to sports clubs under consideration was (160) form and the return (156) form among them (154) form is valid

\section{:Statistical means}

The researcher processed the statistical data by using the statistical program (spss).

\section{RESULT AND DISCUSSION:}

View, analyze and discuss the results of the power axis :Learn about the results of the power axis

Table (5): Shows the calculated value of $\mathrm{t}$ between the theoretical mean and the arithmetic mean of the power axis in the internal environment

\begin{tabular}{|l|l|l|l|l|l|l|}
\hline indication & Error level & computed $(\mathrm{t})$ & The hypothetical medium & $\begin{array}{l}\text { standard } \\
\text { deviation }\end{array}$ & Mediator & Degree \\
\hline moral & 0.000 & 14.65 & 51 & 4.887 & 46 & 45.227 \\
\hline
\end{tabular}

Discuss the results of the power axis

Table shows that the mean of the axis is significantly different from the value of the hypothetical mean and indicates that the sample members have a lower degree than the assumed mean. The researcher believes that the strength axis is one of the axes of the internal environment and has a relationship with the administrative personality or the special characteristics of members of the administrative body or the administrative and leadership capabilities enjoyed by members of the administrative body and this is due to the formation of the administrative personality and to the scientific and practical experiences he possesses in the leadership of the club as well as the power granted to the member from Before the general assembly members, it includes the strengths of the skills and preparations that help the club outperform other clubs in the competition climate, and perhaps the most important factor of strength is the financial and economic management of the club. And the fact that the economy and sports, such as investment, marketing and sports media, are a newly emerging economic approach that emerged in Iraq as a result of political and economic transformations that have appeared in the world and Iraq in particular, and this requires members of administrative bodies to keep abreast of the administrative change process, and to find programs and strategies based on the sustainability of work for the future to build a solid base For the club by sacrificing or postponing some programs and procedures, and here (Muhammad Al-Kalawi) indicates that investment and marketing "is based on sacrifice to satisfy a special consumer desire and not just postpone it just as it is with regard to saving, in the hope of Get more satisfying in the future " This would be a hindrance either to the directions and aspirations of the administrative authorities facing this stage through not achieving them concrete goals, as the weakness of experiences, skills, knowledge and information not members of administrative bodies and their ability to assume responsibility for work as well as developments witnessed by the world's clubs and programs and its openness by working with many diverse economic institutions and informing them All that is new in the outside world and following the precise mechanisms in work and clear evaluation, and this is what the members of the administrative entities are away from in sacrifice or postponing the programs because of their permanent and direct dependence on the financial resources A panel for them and the provision of these financial capabilities by the higher authorities, and this is indicated by (Hassan AlZoghbi) that "the modernity of management information 
(IJRSSH) 2020, Vol. No. 10, Issue No. II, Apr-Jun

systems is to increase the effectiveness of management by satisfying its data and information needs" In addition, there is no realistic investment, marketing, and media narration by club departments, and this is reflected in decision-making and implementation within the club, relying on gifts granted by the state or institutions, and here (Hussam Hassan Shehata) shows that investment, marketing, and media in the sports field is a system of
e-ISSN: 2249-4642, p-ISSN: 2454-4671

decisions The strategy is to operate the assets of sports institutions (financial and human) in order to preserve and develop them to achieve appropriate future returns that help the institution to achieve its sports, economic and social goals in a balanced manner " Therefore, the results were logical.

Presentation, analysis and discussion of the results of the vulnerability axis:

Table (6)

Shows the calculated value of $t$ between the theoretical mean and the mean for the axis of weakness in the internal environment

\begin{tabular}{|l|l|l|l|l|l|l|l|}
\hline indication & Error level & computed $(\mathrm{t})$ & $\begin{array}{l}\text { The } \\
\text { medium }\end{array}$ & $\begin{array}{l}\text { College } \\
\text { degree }\end{array}$ & $\begin{array}{l}\text { the field } \\
\text { deviation }\end{array}$ \\
\hline moral & 0.000 & 8.666 & 51 & 5.542 & 55 & 54.870 \\
\hline
\end{tabular}

:discuss the results of the vulnerability axis

The mean of the axis is significantly different from the value of the hypothetical mean and indicates that the sample members have a greater degree than the assumed mean. The researcher believes that weakness is one of the indicators of the internal environment and has a relationship with the private vision of members of the club's general organization and their interpretation of the policies pursued by the sectoral authorities and the administrative and leadership capabilities enjoyed by members of the administrative body. The most important reasons that the results showed lie in the lack of clarity of the members of the administrative bodies of the goals of sports institutions with respect to both hobby and professionalism or by setting a clear policy for investment, marketing and information for sports facilities and athletes, in addition to the difference of narration between them, and the absence of an administrative body for sports investment, sports marketing and specialized media all of these The reasons led to raising the level of weakness in the field of investment, marketing and sports media, as well as the most important reasons are the method for selecting public bodies for clubs and private laws, as well as the lack of these bodies to sound scientific contexts in how The selection of its members, whether they are administrative or technical, and their position in the specialized and accurate field, which is commensurate with their qualifications, and their ability, which was reflected negatively, on achieving the required goals, which in turn causes economic problems, this negatively affects the process of achieving the goals correctly, and here confirms ( Muhammad Hassan Allawi) "The success of an administrator in his work is closely related to his level, information, knowledge and abilities in the type of specialization that specializes in work in his field. The more distinguished a sports administrator is with a highly specialized qualification, the more he becomes proficient in theoretical knowledge and methods of its application" In addition, there are no specific criteria far from the whims for setting investment and marketing plans and strategies in order to help the administrative bodies to reconsider plans and goals and evaluate their success or failure in the economic aspect and lack of interest and work with comprehensive quality standards that develops the level of performance and increase its efficiency in line with any message An institution and its goals, as evaluating the performance philosophy according to the philosophy of comprehensive quality on the basis of "the involvement of the concerned in evaluation, that is, who aims to evaluate it, and in light of the criteria for evaluating its performance, in order to give the opportunity to improve its achievement through changing 
(IJRSSH) 2020, Vol. No. 10, Issue No. II, Apr-Jun

performance methods or developing product technologies" All these reasons led to a weakness more than expected, so the results appeared logical.

\section{CONCLUSIONS:}

- Sports clubs departments in Iraq have an acceptable level in investment, marketing and sports media for the internal environment (axis of strength) according to the scale (S.W.O.T)

- There is a weakness in the (strength) axis of the internal environment among sports club administrations in Iraq.

- The sports club departments in Iraq have an average level of investment, marketing and media in Riyadh for the internal environment (the axis of weakness) according to the scale (S.W.O.T)

- Sports club departments in Iraq have a weak level of the internal environment in investment, marketing and sports media.
e-ISSN: 2249-4642, p-ISSN: 2454-4671

\section{ENDORSEMENT:}

- Adopting the current scale designed by the researcher to reveal the strengths and weaknesses of the internal environment and the points of opportunities and threats in the external environment of Iraqi sports clubs.

- Investing the strengths and making them an incentive to develop the level of administrative work within sports clubs and to address weaknesses in the internal environment.

- Providing the appropriate environment for the investment and marketing process in sports clubs to increase their financial resources and enable them to build sports facilities, provide equipment and tools, and improve the social and material condition of workers in the sports community.

- Development and promotion of the internal and external environments, investment, marketing and sports media.

\section{REFERENCES:}

- Zakaria Mutlaq Al-Douri: Strategic Management, Concepts, Operations and Study Cases, 1st floor (Amman, Dar Al-Yazouri Publishing and Distribution, 2014).

- Ribhi Mustafa Alyan and Othman Muhammad Ghunaim, Methods and Methods of Scientific Research (Theory and Practice), 1st edition, (Amman Dar Safaa for Publishing and Distribution, 2000).

- Wajih Mahjoub, Scientific Research, (Ministry of Higher Education, Babylon University Press, 2002).

- Muhammad Hassan Allawi and Osama Kamel Ratib: Methods of Scientific Research in Physical Education and Sports Psychology: (Cairo, Dar Al-Fikr Al-Arabi, 1999).

- Mohamed Abdel Salam: Psychological and Educational Measurement, 2nd edition: (Cairo, The Egyptian Renaissance Library, 1981).

- - Mustafa Hussein Bahi: Scientific Transactions between Theory and Practice, Cairo, The Book Center for Publishing, 1999.

Ali Mahdi Kadhim: Building a standardized scale for the characteristics of the preparatory stage in Iraq, Baghdad, PhD thesis, College of Education - Ibn Al-Rushd / University, 1994.

- Faisal Abbas: Psychological Tests - Techniques and Procedures, Beirut Ed., Dar Al-Fikr Al-Arabi, 1996.

- Hossam Hassan Shehata: a proposed system for investment in some Egyptian sports clubs, Ph.D., unpublished, University of Alexandria, 2008.

- Hassan Ali Al-Zoghbi: Strategic Information Systems. Strategic Entry, 1st Floor, Dar Wael, Amman, 2005.

- Hossam Hassan Shehata: a proposed system for investment in some Egyptian sports clubs, Ph.D., unpublished, University of Alexandria, 2008.

- Mohamed Hassan Allawi: Psychology in Athletic Training, Egypt, Dar Al-Maaref, 1978.

- Awad Jassim Muhammad Al-Tamimi: Total Quality Management in Education (Iraq, Baghdad, Ministry of Education, 2004).

- Cronbach,J.(1970):Essentials of Psychological testing. $3^{\text {rd }}$ ed,Harpera Row,New York.

- Freeman , F . S ., Theory and Praction of Psychological Testing, New York, 1962. 
Annex (1)

\begin{tabular}{|c|c|c|c|c|c|c|}
\hline Start & Scarcely & Sometimes & frequently & Always & Paragraphs & sequence \\
\hline & & & & & AXIS OF STRENGTH & \\
\hline & & & & & $\begin{array}{l}\text { Club management puts a new mechanism through modern } \\
\text { ideas for the purpose of change and development in the } \\
\text { concept of investment and marketing. }\end{array}$ & 1 \\
\hline & & & & & $\begin{array}{l}\text { The club members are interested in gathering information } \\
\text { and electronic data about players, good sport performance, } \\
\text { and monitoring sports markets. }\end{array}$ & 2 \\
\hline & & & & & $\begin{array}{l}\text { The club deals with information about existing investment } \\
\text { and marketing through modern technologies. }\end{array}$ & 3 \\
\hline & & & & & $\begin{array}{l}\text { The goals and strategies are clearly and clearly understood } \\
\text { by the club administration for the purpose of } \\
\text { implementation. }\end{array}$ & 4 \\
\hline & & & & & $\begin{array}{l}\text { The club administration has concluded twinning } \\
\text { agreements with distinguished external clubs in order to } \\
\text { exchange experiences and develop administrative work. }\end{array}$ & 5 \\
\hline & & & & & $\begin{array}{l}\text { The club administration organizes marketing and } \\
\text { investment conferences and advertisement opportunities }\end{array}$ & 6 \\
\hline & & & & & $\begin{array}{l}\text { The management of the club provides the best means in } \\
\text { various circumstances and investing them towards } \\
\text { achieving financial returns }\end{array}$ & 7 \\
\hline & & & & & $\begin{array}{l}\text { The club has made publicity about existing investment and } \\
\text { marketing through modern technologies. }\end{array}$ & 8 \\
\hline & & & & & $\begin{array}{l}\text { The relationship between the club and the media helps to } \\
\text { maximize financial revenues, methods, and various } \\
\text { methods in implementing them and achieving goals. }\end{array}$ & 9 \\
\hline & & & & & $\begin{array}{l}\text { The club administration is working to create a suitable } \\
\text { work environment and encourage players and coaches to } \\
\text { participate in sports programs for financial returns. }\end{array}$ & 10 \\
\hline & & & & & $\begin{array}{l}\text { The Olympic Committee and the Ministry of Youth } \\
\text { allocate financial aid to sports clubs }\end{array}$ & 11 \\
\hline & & & & & $\begin{array}{l}\text { The club administration is working to compare what has } \\
\text { been achieved and what has been achieved from the goals } \\
\text { set out in the results. }\end{array}$ & 12 \\
\hline & & & & & $\begin{array}{l}\text { There is a clear vision of loaning players to other clubs } \\
\text { and covering financial expenses }\end{array}$ & 13 \\
\hline & & & & & $\begin{array}{l}\text { The club management is making good investment of the } \\
\text { available material and human capabilities in order to } \\
\text { ensure the development in the games. }\end{array}$ & 14 \\
\hline & & & & & $\begin{array}{l}\text { Sports clubs have become commercial institutions that } \\
\text { increase material gain. }\end{array}$ & 15 \\
\hline & & & & & $\begin{array}{l}\text { Many businesses use sports as a way to spread their } \\
\text { products to the public. }\end{array}$ & 16 \\
\hline
\end{tabular}




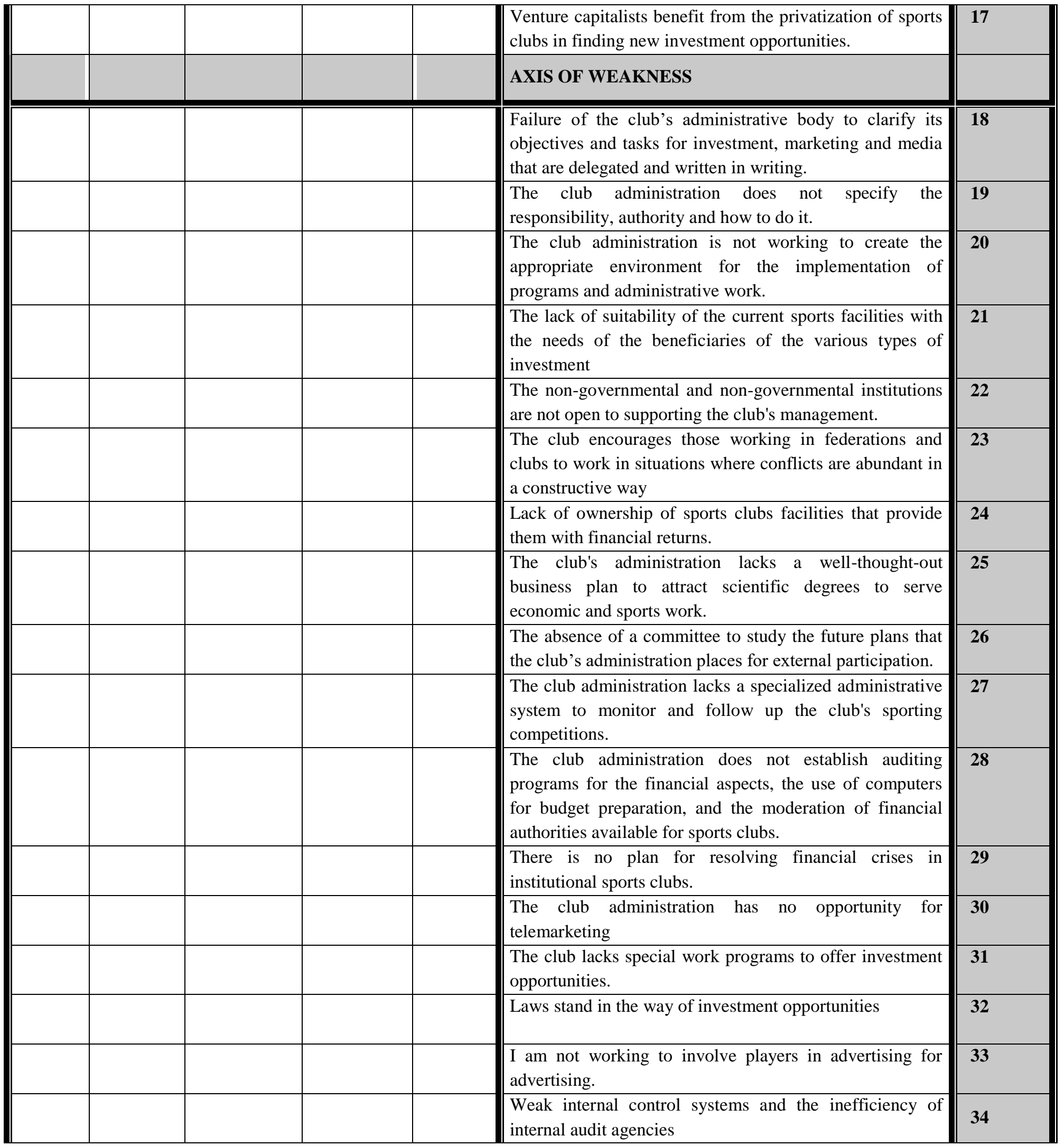

